\title{
Performance Evaluation of Rajshahi Krishi Unnayan Bank (RAKUB) in Bangladesh: An Exploratory Study
}

\author{
Masud Rana \\ Department of Business Administration, Faculty of Business Studies, Pabna University of Science and Technology, Pabna, Bangladesh \\ Email address: \\ Masud7648@gmail.com \\ To cite this article: \\ Masud Rana. Performance Evaluation of Rajshahi Krishi Unnayan Bank (RAKUB) in Bangladesh: An Exploratory Study. Journal of \\ Finance and Accounting. Vol. 4, No. 2, 2016, pp. 71-80. doi: 10.11648/j.jfa.20160402.17
}

Received: March 24, 2016; Accepted: March 30, 2016; Published: April 15, 2016

\begin{abstract}
Rajshahi Krishi Unnayan Bank (RAKUB) plays an important role in the economic development of the Bangladesh especially for financing the farmers of the 16 districts of Rajshahi and Rangpur in Bangladesh. Agriculture remains the most important sector of Bangladeshi economy, contributing 19.6 percent to the GDP and providing employment for 63 percent of the population. A plurality of Bangladeshis earn their living from agriculture. The performance of this sector has an overwhelming impact on the overall economic development of the country. For efficient performance of this sector proper credit facilities and adequate support is essential both from government and private sector. The main objective of the study is to analyze the financial performance of Rajshahi Krishi Unnayan Bank, Bangladesh. It is observed that RAKUB is able to achieve a steady growth in terms of employees, branches, deposits, loans and advances during the period 2009-2014. Different trend equations and square of correlation coefficient $\left(\mathrm{r}^{2}\right)$ have been tested for different activities of Rajshahi Krishi Unnayan Bank, Bangladesh. Finally, results are interpreted in this context and suggestions are given for improving the future performance of this bank.
\end{abstract}

Keywords: Financial Performance, Deposit, Loan, Equity, Rajshahi Krishi Unnayan Bank, Bangladesh

\section{Introduction}

The evolution of Bangladesh made through the "Great Liberation War" on 16 December in 1972. After independence of Bangladesh "Pakistan Krishi Unnayan Bank" was renamed as "Bangladesh Krishi Unnayan Bank". Control of flood, rice of new quality and introduction of other high yielding crops and the increasing demand of its, institutional loan demand of farmer increased. Since Bangladesh is an agro-based country; the demand for the loan of Krishi Bank has been increased remarkably. It becomes very difficult for a Dhaka based head office of Krishi Bank to manage agro-loan in the remote areas of the country. For this reason, government felt to decentralize the Krishi Bank in the divisional areas and Rajshahi division was first choice. The Northern areas of Bangladesh were not developed in comparison with other areas of Bangladesh; it is one of the main reasons of establishing RAKUB. Institutional agriculture credit plays a crucial role in the modernization of agriculture. Adequate flow of credit can remove the financial constraints of the farmers and provide the incentive to adopt new technologies that would otherwise be more slowly accepted. Credit facilities also help the process of commercialization of subsistence agriculture. RAKUB realized this situation and performed their job tremendously.

Development of agro-based industries, self-employment, solving unemployment problems, providing money for expansion of socio-economic activities and provide consultancy are the main objective of establishing RAKUB. In the very beginning of RAKUB, the number of branches was 253 . Now the number of branches is 377 . At his outset of bank, the credit balance was TK. 610 crores and now credit balance is Tk. 1469 crores. This bank is continuously trying to provide support for the advancement and development of the agricultural sector of the country. First of all, they are promoting savings, mostly from middle and lower middle class of urban and rural people. Secondly these banks promote investment in different sectors of agriculture, industry and trade. They either invest directly or advances loan to the investors. They are continuously helping the 
disadvantaged people to become self sufficient by providing them micro credit. For the well being of all industries farmers in the northwest region in Bangladesh, RAKUB is continuing relentless efforts and taking more than one hundred and seven loan programs.

\subsection{Review of Literature}

Chien and Danw (2004) showed in their study that most previous studies concerning company performance evaluation focus merely on operational efficiency and operational effectiveness, which might directly influence the survival of a company. By using an innovative two-stage data envelopment analysis model in their study, the empirical result of this study is that a company with better efficiency does not always means that it has better effectiveness.

Chowdhury (2002) identified that the banking industry of Bangladesh is a mixed one comprising nationalized, Private and foreign banks. Many efforts have been made to explain the performance of these banks. Understanding the performance of the bank requires knowledge about the profitability and the relationship between variables like market size, banks risk and banks market size with the profitability.

Khan (2008) stated that bank is evaluated based on profit and loss as the same way for other business. If the shareholders of the bank get more profit then the bank is identified as successful. Banks can attain success if relevant risks are effectively controlled.

Bingham and Houston (2004) found that performance evaluation is one of the important issues for any bank especially for private commercial banks because a link exists between performance and profit earning. It also helps a bank to determine how well it is performing in compare to others. Performance evaluation is needed for a bank to position itself in a way to see what are needed to add, remove or change to improve the current condition. Simply how well the bank is using its resources to earn profit it indicated by its performance evaluation

Swampy and Vasudevan (1985) stated that in measuring performance level of a bank, some variables like employee, deposits, loan and advances, profits etc. are used. These variables help the selected bank to evaluate the overall performance of the bank. The increasing number of employees, larger amount of deposit, more loan disbursement, and higher profitability indicate that the bank is performing well and in some cases better than before.

Hwag, Lee, Lin and Ouyang (2009) took into consideration of both financial and nonfinancial performances when evaluating 35 sampled publicly traded commercial banks in Taiwan. The banks are classified based on the year founded and the type of major stockholders. They found that the privatized government owned banks have significantly performed better than private banks. New and old banks are not significantly different from each other in both financial and nonfinancial performance indexes. They concluded that more branch offices, better capital structure and solvency, higher growth in deposits and loans result in more profits, and lead to higher customer satisfaction and more efficient management.

Khalily, Huda and Lalarukh (1997) identified that credit is necessary for agricultural development vis-à-vis rural economic development. But loan recovery rate is low. This has adverse impact on revolving of loan able fund and viability of rural financial system. Poor performance of lenders in agricultural credit does affect viability of rural financial system. A quick estimate shows that social cost of forgiveness program has been twenty five percent of loan outstanding. On the other hand continued interest of the political lenders in interest and loan forgiveness program also affects expected recovery behavior of the borrowers. Burden of social cost for agricultural or rural credit cannot be fully attributed to crop loans as it constitutes only forty percent of the total agricultural credit. Non crop loans are likely to be less risky. Therefore, the problem of high social cost for agricultural credit can perhaps be linked to institutional behavior.

Ahmad (2011) said that the financial performance of seven Jordanian commercial banks. He used the ROA as a measure of banks' performance and the bank size, asset management and operational efficiency as three independent variables affecting ROA. The results of his analysis revealed a strong negative correlation between ROA and banks' size, a strong positive correlation between ROA and asset management ratio, and a negative weak correlation between ROA and operational efficiency.

Siddique and Islam (2001) examined that the commercial banks, as a whole are performing well and contributing to the economic development of the country. The average profitability of all Bangladeshi Banks collectively was $0.09 \%$ during 1980 to 1995 which means that a profit of Tk.0.09 was earned by utilizing assets of Tk.100 in every aspect of profit; banking sector contributes the national economy as well as the individual organization. Despite overall growth of the banking sector positive the performance of different categories of banks were not equally attractive.

\subsection{Objectives of the Study}

The main objective of the study is to analyze the financial performance of Rajshahi Krishi Unnayan Bank, Bangladesh.

The specific objectives of the study are:

- To get an overall idea about the financial position of Rajshahi Krishi Unnayan Bank, Bangladesh.

- To evaluate the financial performance of the Rajshahi Krishi Unnayan Bank, Bangladesh.

- To suggest some policy guidelines for improving the problems involved in Rajshahi Krishi Unnayan Bank, Bangladesh.

\subsection{Methodology of the Study}

Methodology is a system of broad principle or rule from which specific methods or procedures may be derived to interpret or solve different problems within the scope of a particular discipline. Methodology is not a formula but set of 
practices. This study has been based mainly on data from secondary sources. The relevant data and information were collected from Stock Exchanges, Annual Reports of Rajshahi Krishi Unnayan Bank, Bangladesh, Bangladesh Bank, Securities and Exchange Commission and web sites of Rajshahi Krishi Unnayan Bank, Bangladesh etc. Relevant articles and literature in this context have also been consulted. In this article I analyzed last six years data of Rajshahi Krishi Unnayan Bank, Bangladesh.

\subsubsection{Choice of the Period}

The most recent fiscal year of disclosure has been chosen for using the updated information for the study. The fiscal year from 2009 to 2014 has been selected to analyze the financial statements in the annual report of the banks.

\subsubsection{Tools for Analysis}

Six trend equations have been tested for different activities of the Rajshahi Krishi Unnayan Bank, Bangladesh\& Square of correlation coefficient $\left(\mathrm{r}^{2}\right)$ has also been tested for all trend equations as well as growth percentage is also used in this analysis. Among the various straight line Trend Methods of Time Series Analysis the method of Least Square is most popular and widely used in practice. The method of least square can be used either to fit a straight-line trend or a parabolic trend. The straight line trend is represented by the equation $\mathrm{Yc}=\mathrm{a}+\mathrm{b}$. Where, Yc denotes the trend values to distinguish them from the actual $Y$ values. ' $a$ ' is the $Y$ intercept or the value of the $Y$ variable when $X=0$. ' $b$ ' represents the slope of the line of the amount of change in $Y$ variable that if associated with a change of one unit in $X$ variable. ' $\mathrm{X}$ ' variable in time series analysis represents time. The square of correlation coefficient $\left(\mathrm{r}^{2}\right)$ is called the multiple determinations or squared multiple correlation coefficients. The coefficient of correlation is denoted by $r$. The value of $r$ lies between 0 and 1 . The higher the $r^{2}$ the greater the percentage of the variation of $\mathrm{Y}$ explained by the regression model, that is, the better the "goodness of fit" of the regression model to the sample observations. $r^{2}$ closer to zero, the worse the fit.

\subsubsection{Content Analysis}

This paper measure the performance based on financial statements from 2009 to 2014 of Rajshahi Krishi Unnayan Bank, Bangladesh. Under 6 financial criteria i.e. Growth of Branches, Employees, Deposits, Classified Loan, Operating Profit/Loss and Capital adequacy ratios.

\section{An over View of RAKUB}

Rajshahi Krishi Unnayan Bank is a state-owned bank in Bangladesh, a specialized financial institution for financing the farmers of the 16 districts of Rajshahi and Rangpur, which are administrative divisions comprising the northwest Bangladesh. Established by the President's Ordinance No. 58 of 1986, the bank started functioning on 15 March 1987. The bank emerged as the government's aim of providing intensive care to the agriculture of Rajshahi and
Rangpur Divisions, providing livelihood to 35 million people of the area. The region is full of agricultural potentials. The Rajshahi and Rangpur divisions are characterized by their surplus food grain production, and are popularly called the "granary of the country". Besides catering to agricultural credit, RAKUB, as Rajshahi Krishi Unnayan Bank is acronymed, renders deposit banking services through all its 368 branches in Rajshahi and Rangpur, including one in Dhaka. The headquarters of the bank is stationed at Rajshahi, about 270 kilometers to the north of Dhaka.

\subsection{Management}

Management of the bank is entrusted by the government to a seven-member board of Directors. Managing Director is the chief executive of the bank.

\subsection{Activities of RAKUB}

The bank takes pride in being the largest development partner in the northwest region of Bangladesh. RAKUB aims at overall development of farmers and all the sectors and subsectors of agriculture in this region. The bank also performs functions like financing agri-business and agro-based industries and poverty alleviation programs.

\subsection{Credit Facilities}

\subsubsection{Crop Production}

The Bank finances for production of all the summer and winter crops, horticulture \& nursery etc. High yielding and high value crops and seeds production is particularly encouraged. Crop sub-sector alone occupies $60 \%$ of the lending budget of the Bank.

\subsubsection{Livestock and Poultry}

The Bank extends credit facilities for systematic and commercial livestock farming which includes dairy, beeffattening, poultry, raising and setting up of hatcheries which in turn is expected to increase production of milk, meet and eggs, the main source of protein. As the marginal and small farmers access to mechanized farming is restrained by want of cash and collateral, the bank has a big lending window of draft animals for cultivation of land, transportation of agricultural produces and other farming activities.

\subsubsection{Fishery}

The Bank attaches importance to use scientific method and modern technology in fish cultivation. It extends adequate credit support for excavation and re-excavation of ponds, round the year cultivation of species, which have rapid growth, cultivation of sweet water prawn and other fishes. The Bank makes use of expertise of the concerned government agencies for bringing more ponds/water bodies under cultivation and increasing productivity.

\subsubsection{Irrigation Equipment \& Farm Machinery}

In today's technology-based farming of high yielding and high-value crops, mechanization of cultivation, irrigation and 
pest-control is indispensable. To cope with the situation financing power tillers, tractors, tube wells, power-pumps, fertilizer and pesticide application devices.

\subsubsection{Agro-industry \& Agri-business}

The operational jurisdiction of the Bank is noted for its agricultural potentials. The Bank pays due importance to setting up agro-industries for preservation, processing and marketing of agricultural produces having backward linkage with basic sub-sectors of crop, fishery, livestock and forestation. Manufacturing and marketing of agricultural implements are also encouraged. Agro-industries for import sub situation are specially encouraged by offering moderate terms of financing.

\subsubsection{Poverty Alleviation}

The poverty-stricken area of north-west Bangladesh is characterized by comparatively lower rate of savings, inadequate capital accumulation and slim employment opportunities. The existing collateral-based banking system is also of little use in respect of extending support to the millions of landless people. To address the problem, the Bank has been financing collateral-free micro-credit for income and employment generation through its poverty alleviation credit programs.

\subsection{Deposit}

The bank gives importance to accumulation of rural small savings through its branches. RAKUB renders all sorts of deposit banking services to its over one million valued customers. The bank operates deposit accounts like Savings Bank Accounts, Current Deposit accounts, Short Notice Deposit Accounts \& Fixed Deposit Account and different saving schemes.

Type of deposit account (with interest rate):

- Savings Bank Account (Urban Area) - 5.00 percent
- Savings Bank Account (Rural Area) - 7.00 percent

- Short Notice Deposit Account (SND) - 4-5.00 percent

- Current Deposit Account - 0.00 percent

- Fixed Deposit Receipt (FDR) Account

- from 1 months to below 3 months -8.00 percent

- from 3 months to below 6 months -8.50 percent

- from 6 months to below 1 years - 9.00 percent

- from 1 years to below 2 years - 9.25 percent '

- Krishok Sanchoy Scheme (KSS)

- RAKUB Sanchoy Scheme (RSS)

- RAKUB Double Money Scheme (RDMS)

- RAKUB Triple Money Scheme (RTMS)

- RAKUB Daily Profit (RDP)

\section{Performance Evaluation of RAKUB in Bangladesh}

\subsection{Growth of Branches of RAKUB}

Table 1. Growth of Branches of RAKUB.

\begin{tabular}{llll}
\hline Serial No. & Year & Number of the Branches & Growth \\
\hline 1 & $2009-2010$ & 365 & \\
2 & $2010-2011$ & 367 & $0.55 \%$ \\
3 & $2011-2012$ & 374 & $1.91 \%$ \\
4 & $2012-2013$ & 376 & $0.53 \%$ \\
5 & $2013-2014$ & 377 & $0.27 \%$ \\
\hline
\end{tabular}

Source: Own analysis based on annual reports of Rajshahi Krishi Unnayan Bank, Bangladesh.

Table 1 shows the growth pattern of number of branches of Rajshahi Krishi Unnayan Bank, Bangladesh.

The growth of branches is positive for every year i.e. upward trends. But, in 2013-2014 has highest number of Branches i.e. 377 .The highest growth percentage is in 20112012 \& lowest is in 2013-2014.

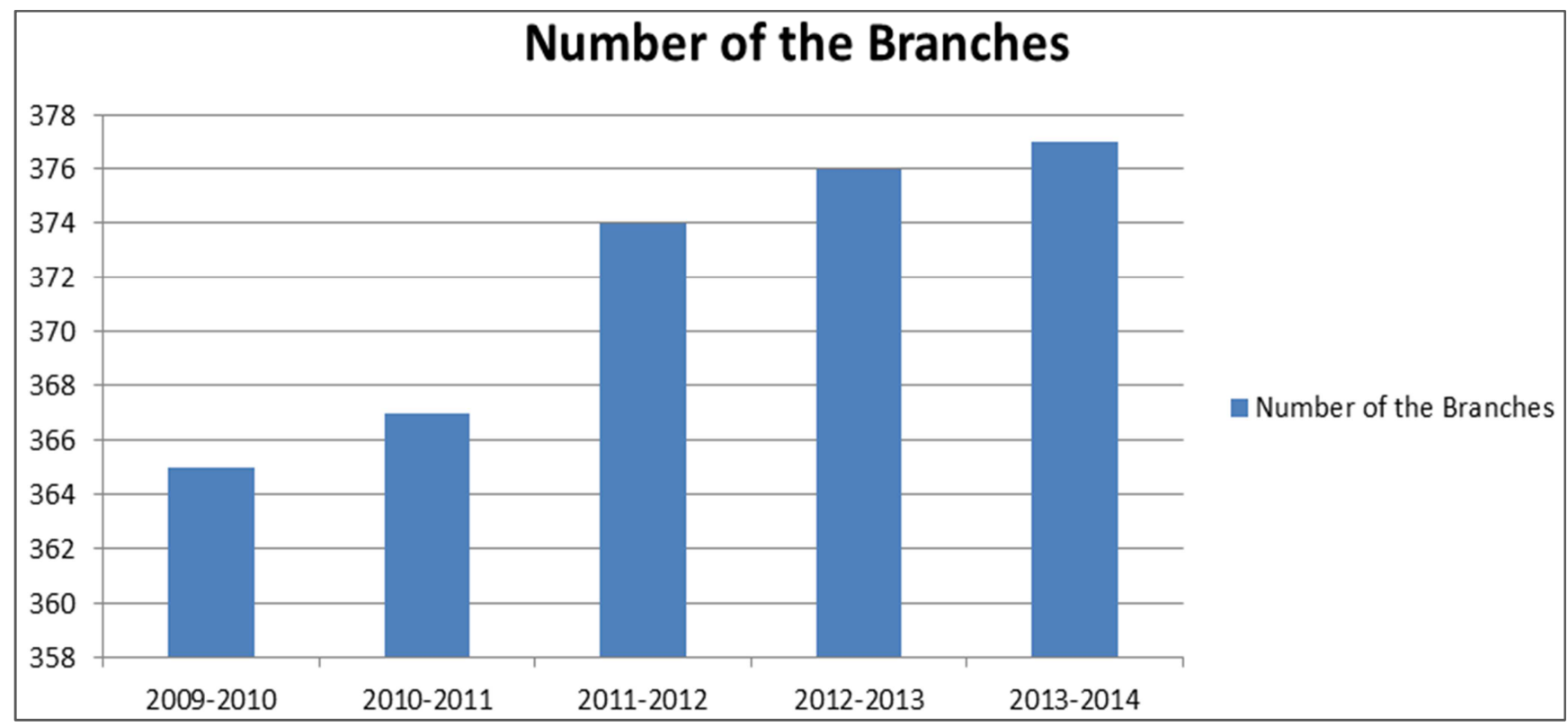

Figure 1. Number of Branches of RAKUB. 


\subsection{Trend Equation and $r^{2}$ of Branches}

$\mathrm{Yc}=\mathrm{a}+\mathrm{bx}=361.90+3.3 \mathrm{x}$

$$
r^{2}=0.917
$$

Trend equation is reflected from the table 1 that trend equation of Rajshahi Krishi Unnayan Bank is positive and goodness of fit of equation is very high i.e. 0.917 .

\subsection{Growth of Employees of RAKUB}

Table 2 shows the growth pattern of number of employees of Rajshahi Krishi Unnayan Bank, Bangladesh.

The growth of employees is positive in year 2011-2012, 2012-2013 and negative in year 2010-2011, 2013-2014. But, in 2012-2013 has highest number of employees i.e. 3598 . The highest growth percentage is in 2011-2012 and lowest growth percentage is in 2010-2011.

Table 2. Growth of Employees of RAKUB.

\begin{tabular}{llll}
\hline Serial No. & Year & & Growth \\
\hline 1 & $2009-2010$ & 3387 & \\
2 & $2010-2011$ & 3328 & $-1.77 \%$ \\
3 & $2011-2012$ & 3462 & $4.03 \%$ \\
4 & $2012-2013$ & 3598 & $3.93 \%$ \\
5 & $2013-2014$ & 3540 & $-1.64 \%$ \\
\hline
\end{tabular}

Source: Own analysis based on annual reports of Rajshahi Krishi Unnayan Bank, Bangladesh.

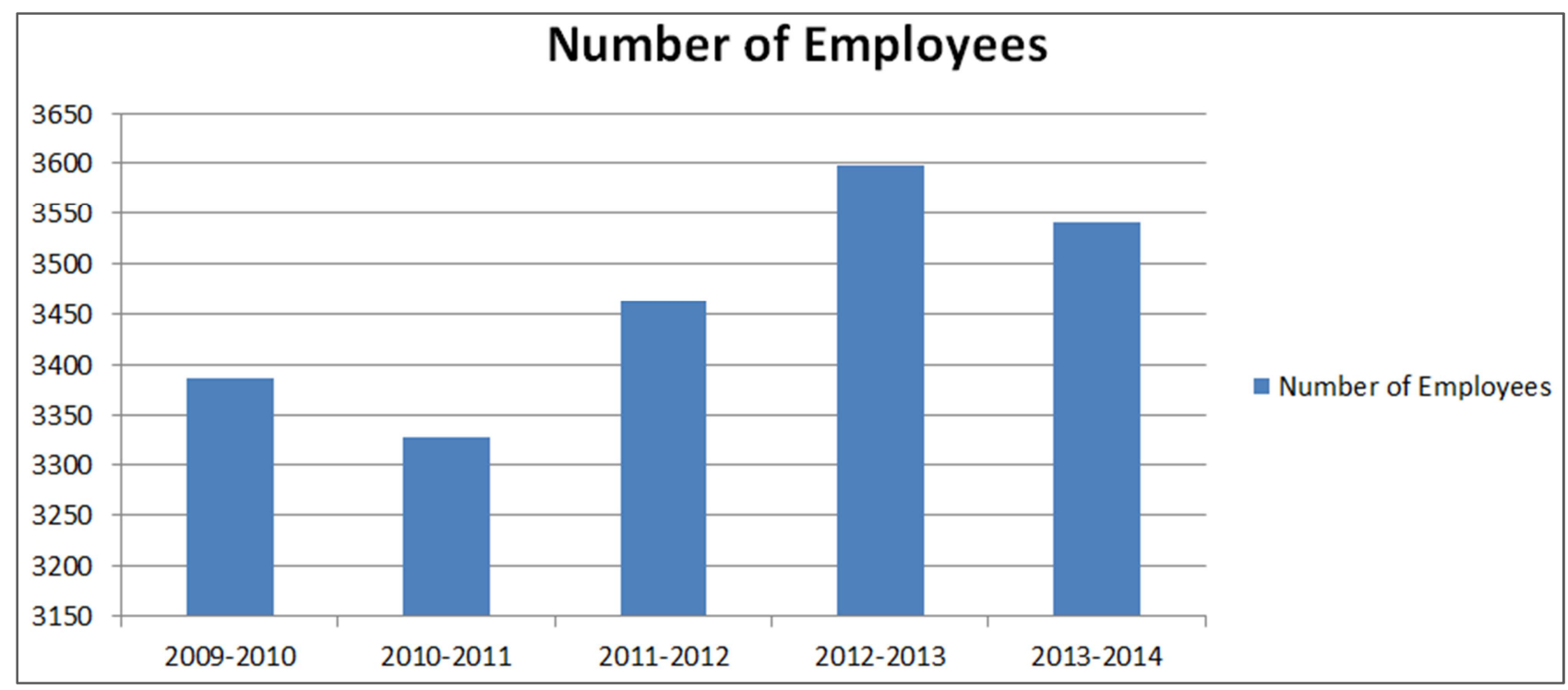

Figure 2. Number of Employees of RAKUB.

\subsection{Trend Equation and $r^{2}$ of Employees}

$$
\mathrm{Yc}=\mathrm{a}+\mathrm{bx}=3290.20+57.6 \mathrm{x}
$$$$
r^{2}=0.689
$$

Trend equation is reflected from the table 2 that trend equation of Rajshahi Krishi Unnayan Bank is positive and goodness of fit of equation is very high i.e. 0.689.

\subsection{Growth of Deposits of RAKUB}

Table 3. Growth of Deposits of RAKUB: (Figure in Crore).

\begin{tabular}{llll}
\hline Serial No. & Year & Deposits & Growth \\
\hline 1 & $2009-2010$ & 2067.28 & \\
2 & $2010-2011$ & 1946.42 & $-6.21 \%$ \\
3 & $2011-2012$ & 1953.44 & $0.36 \%$ \\
4 & $2012-2013$ & 2228.58 & $14.08 \%$ \\
5 & $2013-2014$ & 3050.13 & $36.86 \%$ \\
\hline
\end{tabular}

Source: Own analysis based on annual reports of Rajshahi Krishi Unnayan Bank, Bangladesh.

Table 3 shows the growth pattern of deposits of Rajshahi Krishi Unnayan Bank, Bangladesh. The growth of deposit is positive for every year but negative in year 2010-2011. In year 2013-2014 has highest deposit i.e. 3050.13Crore.The highest growth percentage is in 2013-2014\& lowest is in 2010-2011.

\subsection{Trend Equation and $r^{2}$ of Deposits}

$$
\begin{aligned}
& \mathrm{Yc}=\mathrm{a}+\mathrm{bx}=1574.81+224.79 \mathrm{x} \\
& \mathrm{r}^{2}=.592
\end{aligned}
$$

Trend equation is reflected from the table 3 that trend equation of Rajshahi Krishi Unnayan Bank is positive and goodness of fit of equation is high i.e. 0.592.

\subsection{Growth of Classified Loan of RAKUB}

Table 4. Growth of Classified Loan of RAKUB: (Figure in Crore).

\begin{tabular}{llll}
\hline Serial No. & Year & Classified Loan & Growth \\
\hline 1 & $2009-2010$ & 1313.14 & \\
2 & $2010-2011$ & 1308.07 & $-0.39 \%$ \\
3 & $2011-2012$ & 1380.07 & $5.50 \%$ \\
4 & $2012-2013$ & 1520.38 & $10.17 \%$ \\
5 & $2013-2014$ & 1469.47 & $-3.46 \%$ \\
\hline
\end{tabular}

Source: Own analysis based on annual reports of Rajshahi Krishi Unnayan Bank, Bangladesh. 
Table 4 shows the growth pattern of classified loan of Rajshahi Krishi Unnayan Bank, Bangladesh. The growth of classified loan is positive in year 2011-2012, 2012-2013 and negative in year 2010-2011, 2013-2014. But, in 2012-2013 has highest amount of classified loan i.e. 3598. The highest growth percentage is in 2012-2013 and lowest growth percentage is in 2013-2014.

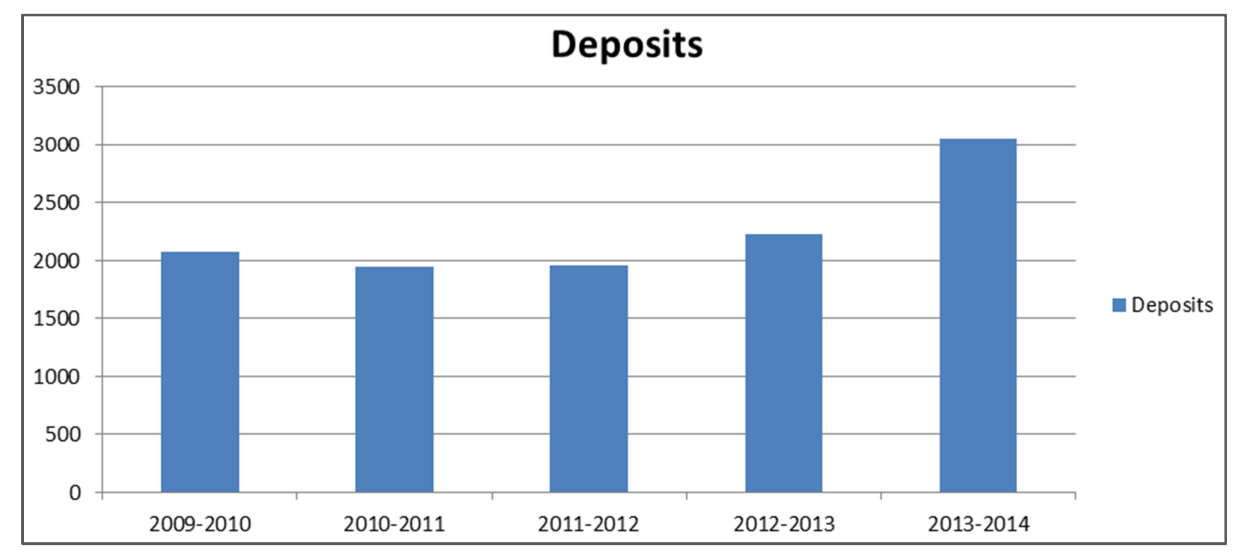

Figure 3. Amount of Deposits of RAKUB.

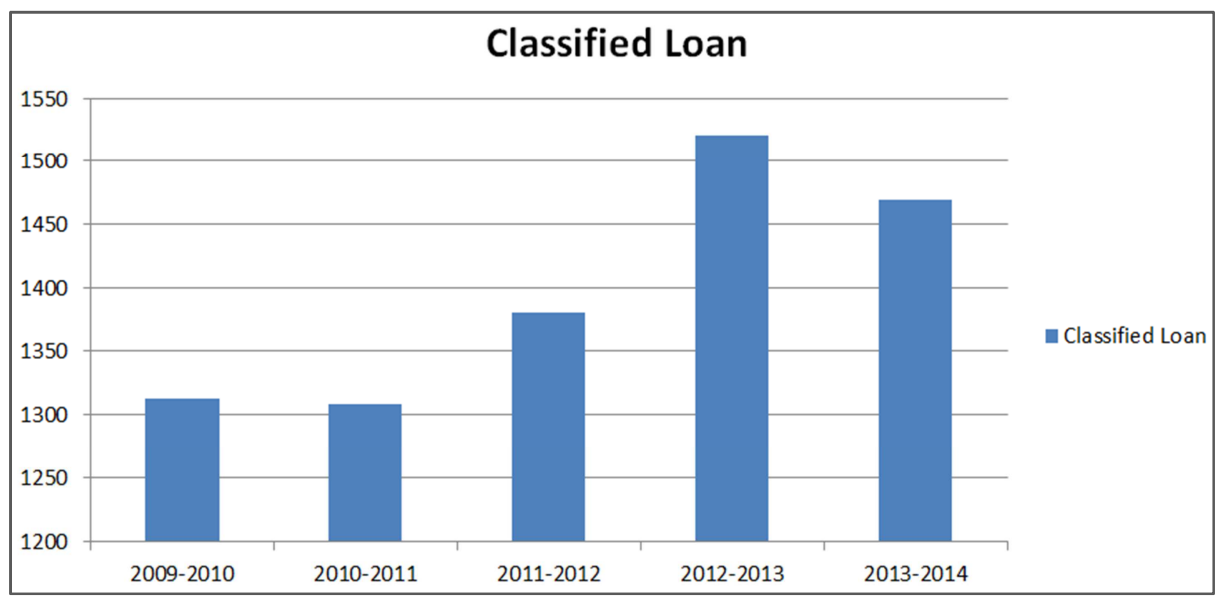

Figure 4. Amount of Classified Loan of RAKUB.

\subsection{Trend Equation and $r^{2}$ of Classified Loan}

$\mathrm{Yc}=\mathrm{a}+\mathrm{bx}=1240.74+52.5 \mathrm{x}$

$\mathrm{r}^{2}=.772$

Trend equation is reflected from the table 4 that trend equation of Rajshahi Krishi Unnayan Bank is positive and goodness of fit of equation is very high i.e. 0.772

\subsection{Operating Income, Expense, and Profit/Loss of $R A K U B$}

Table 5. Operating Income, Expense, and Profit/Loss of RAKUB: (Figure in Crore).

\begin{tabular}{lllll}
\hline $\begin{array}{l}\text { Serial } \\
\text { No. }\end{array}$ & Year & $\begin{array}{l}\text { Operating } \\
\text { Income }\end{array}$ & $\begin{array}{l}\text { Operating } \\
\text { Expense }\end{array}$ & $\begin{array}{l}\text { Operating } \\
\text { Profit/Loss }\end{array}$ \\
\hline 1 & $2009-2010$ & 326.01 & 320.79 & 5.22 \\
2 & $2010-2011$ & 315.26 & 365.60 & -50.34 \\
3 & $2011-2012$ & 332.89 & 370.53 & -37.64 \\
4 & $2012-2013$ & 370.13 & 397.68 & -27.55 \\
5 & $2013-2014$ & 434.36 & 441.44 & -7.08 \\
\hline
\end{tabular}

Source: Own analysis based on annual reports of Rajshahi Krishi Unnayan Bank, Bangladesh.
Table 5 shows the amount of operating income, expense, and profit/loss of Rajshahi Krishi Unnayan Bank, Bangladesh. Amount of operating expense is more than amount of operating income in every year except in year 2009-2010.

\subsection{Statement of Profit and Loss of RAKUB}

Table 6. Statement of Profit and Loss of RAKUB.

\begin{tabular}{|c|c|c|c|c|c|c|}
\hline $\begin{array}{l}\text { Serial } \\
\text { No. } \\
\end{array}$ & Year & $\begin{array}{l}\text { Total } \\
\text { Income }\end{array}$ & $\begin{array}{l}\text { Total } \\
\text { Expense } \\
\end{array}$ & Profit & Loss & $\begin{array}{l}\text { Accumulated } \\
\text { Loss }\end{array}$ \\
\hline 1 & $\begin{array}{l}2009- \\
2010\end{array}$ & 326.03 & 350.80 & ----- & 24.77 & 365.86 \\
\hline 2 & $\begin{array}{l}2010- \\
2011\end{array}$ & 315.26 & 385.60 & ----- & 70.34 & 436.21 \\
\hline 3 & $\begin{array}{l}2011- \\
2012\end{array}$ & 332.89 & 400.53 & ----- & 67.64 & 503.85 \\
\hline 4 & $\begin{array}{l}2012- \\
2013\end{array}$ & 370.82 & 428.95 & ----- & 58.82 & 562.67 \\
\hline 5 & $\begin{array}{l}2013- \\
2014\end{array}$ & 434.36 & 947.52 & ----- & 513.17 & 1035.83 \\
\hline
\end{tabular}

Source: Own analysis based on annual reports of Rajshahi Krishi Unnayan Bank, Bangladesh. 
Table 6 shows the amount of total income, total expense, and profit/loss of Rajshahi Krishi Unnayan Bank,

Bangladesh. Amount of expense is more than amount income of in every year and every year incurred loss.

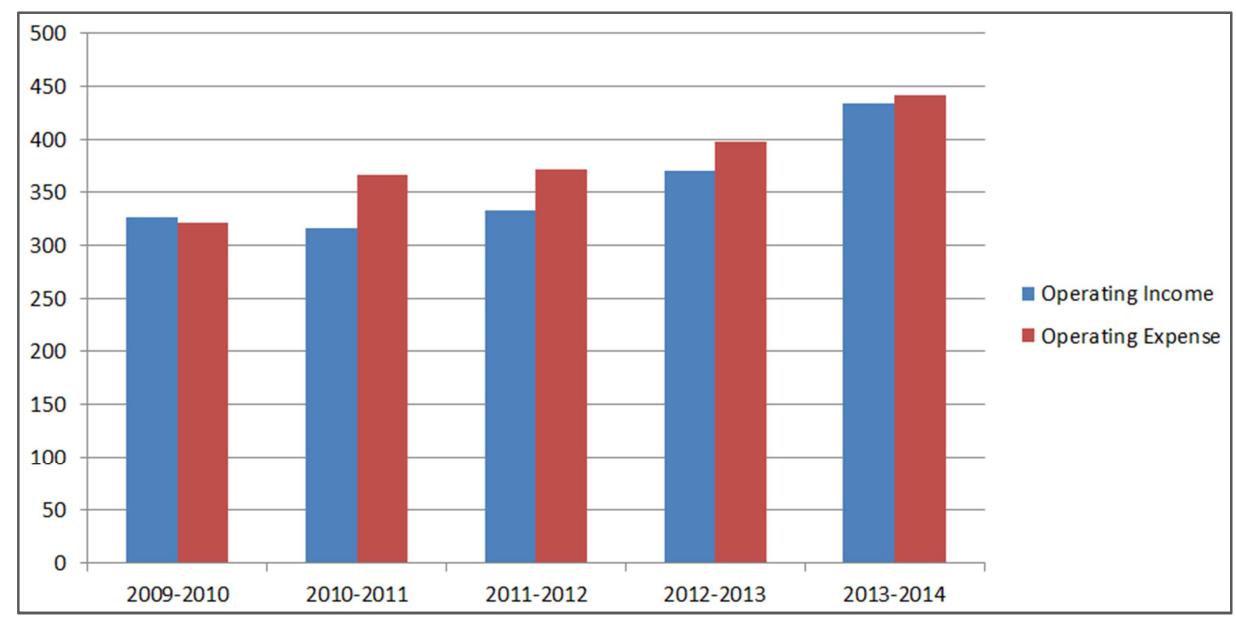

Figure 5. Amount of Operating Income and Operating Expense of RAKUB.

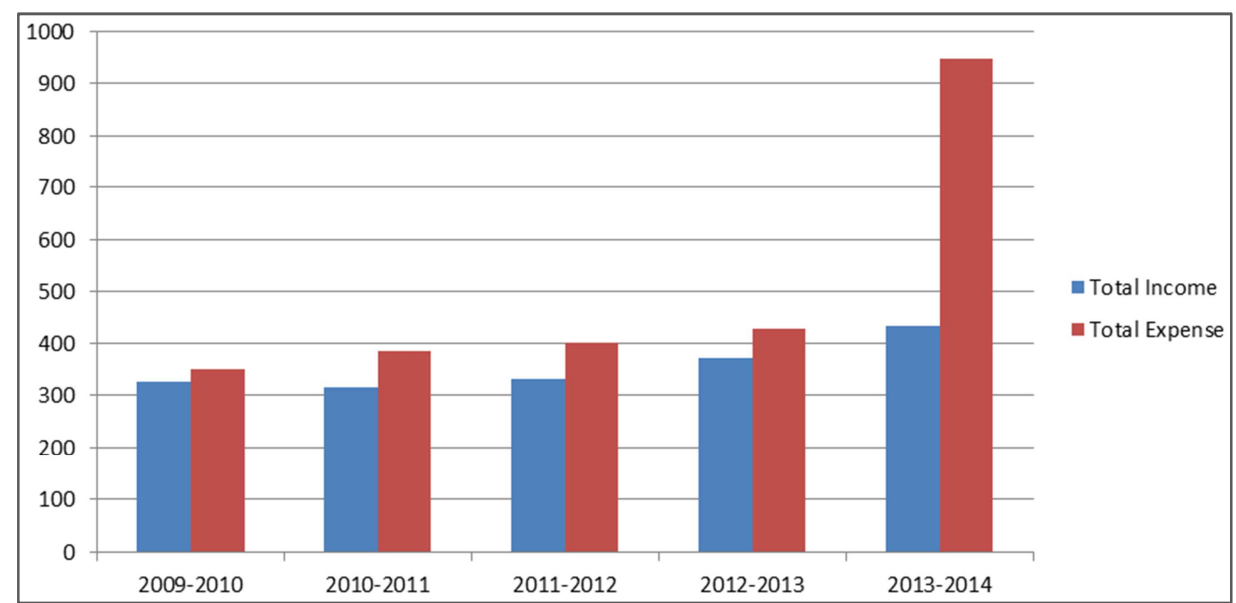

Figure 6. Amount of Total Income and Total Expense of RAKUB.

\subsection{Scenario of Capital of RAKUB}

Table 7. Scenario of Capital of RAKUB: (Figure in Crore).

\begin{tabular}{|c|c|c|c|c|c|c|}
\hline Serial NO. & Particular & 2009-2010 & 2010-2011 & 2011-2012 & 2012-2013 & 2013-2014 \\
\hline \multirow{7}{*}{ (A) } & Total Risk Weighted Assets (RWA) & 3051.13 & 3116.99 & 3220.89 & 3346.25 & 3874.23 \\
\hline & Capital Required @ 10\% of RWA or $10 \%$ RWA $\geq 400.00$ & 244.09 & 280.53 & 322.10 & 334.62 & 387.42 \\
\hline & Core Capital & & & & & \\
\hline & Fully Paid-up Capital/Capital lien with BB & 570.00 & 570.00 & 570.00 & 570.00 & 570.00 \\
\hline & Statutory Reserve & ----- & ----- & ----- & ---- & ---- \\
\hline & General Reserve & 20.85 & 20.85 & 20.85 & 20.85 & 20.85 \\
\hline & Retained Earnings & -365.86 & -436.21 & -503.84 & -562.67 & -1075.83 \\
\hline \multirow{8}{*}{ (B) } & Sub-Total & 224.99 & 154.64 & 87.01 & 28.18 & -484.98 \\
\hline & Less: Provision Shortfall against loan \& advances & 156.14 & 170.41 & 209.06 & 309.75 & ----- \\
\hline & Less: Provision Shortfall against other assets & ----- & ----- & ----- & 233.97 & ----- \\
\hline & Total Eligible Tier-1 Capital & 68.85 & -15.77 & -122.05 & -515.54 & -484.98 \\
\hline & Supplementary Capital: & & & & & \\
\hline & a) Provision maintained against unclassified loan. & 59.32 & 62.78 & 68.61 & 74.52 & 83.53 \\
\hline & $\begin{array}{l}\text { b) Deduction (the amount of tire } 2 \text { capital will be limited to } \\
100 \% \text { of the amount of tire } 1 \text { capital) }\end{array}$ & ---- & ---- & 68.61 & 74.52 & 83.53 \\
\hline & Total Eligible Tier-2 Capital & 59.32 & 62.78 & 0.00 & 0.00 & ---- \\
\hline (C) & Total Eligible Tier-1 \& Tier-2 Capital & 128.17 & 47.01 & -122.05 & -515.54 & -484.98 \\
\hline (D) & Regulatory Capital against 1 st pillar & 244.09 & 280.53 & 400.00 & 400.00 & 400.00 \\
\hline (E) & Capital Surplus/ Shortfall against 1st pillar of Basel II & -115.92 & -233.52 & -522.05 & -915.54 & -884.98 \\
\hline
\end{tabular}

Source: Own analysis based on annual reports of Rajshahi Krishi Unnayan Bank, Bangladesh. 


\subsection{Capital Adequacy Ratios (CAR) of RAKUB}

$\mathrm{CAR}=($ Tier one capital + Tier two capital $) /$ Risk Weighted Assets

Table 8. Capital adequacy ratios (CAR) of RAKUB.

\begin{tabular}{lll}
\hline Serial NO. & Year & CAR \\
\hline 1 & $2009-2010$ & 4.20 \\
2 & $2010-2011$ & 1.51 \\
3 & $2011-2012$ & -3.79 \\
4 & $2012-2013$ & -15.41 \\
5 & $2013-2014$ & -12.52 \\
\hline
\end{tabular}

Source: Own analysis based on annual reports of Rajshahi Krishi Unnayan Bank, Bangladesh.

Capital adequacy ratio is a measure of a bank's capital. It is expressed as a percentage of a bank's risk weighted credit exposures. This ratio is used to protect depositors and promote the stability and efficiency of financial systems around the world. Growth pattern fluctuate from one year to another year. But the fluctuation range was big, so it indicates that the financial system of Rajshahi Krishi Unnayan Bank, Bangladeshis not stable.

\section{Summary of the Findings of the Study}

Rajshahi Krishi Unnayan Bank is a state-owned bank in Bangladesh, a specialized financial institution for financing the farmers of the 16 districts of Rajshahi and Rangpur, which are administrative divisions comprising the north-west Bangladesh. Established by the President's Ordinance No. 58 of 1986, the bank started functioning on 15 March 1987. The banks create employment opportunities for more than four thousand people. The highest employee growth percentage is in 2011-2012 and lowest growth percentage is in 2010-2011. From the trend analysis we have observed that $\left(\mathrm{r}^{2}\right)$ of employees of the banks are more than $68 \%$. The growth of branches is positive for every year i.e. upward trends. But, in 2013-2014 has highest number of Branches i.e. 377.The highest growth percentage is in 2011-2012 \& lowest is in 2013-2014. Trend equation of branches of Rajshahi Krishi Unnayan Bank is positive and goodness of fit of equation is very high i.e. $90 \%$.The growth of deposit is positive for every year but negative in year 2010-2011. In year 2013-2014 has highest deposit i.e. 3050.13 Crore. The highest growth percentage is in 2013-2014 \& lowest is in 2010-2011. Trend equation of deposit of Rajshahi Krishi Unnayan Bank is positive and goodness of fit of equation is high i.e. $59 \%$. The growth of classified loan is positive in year 2011-2012, 20122013 and negative in year 2010-2011, 2013-2014. But, in 2012-2013 has highest amount of classified loan i.e. 3598 . The highest growth percentage is in 2012-2013 and lowest growth percentage is in 2013-2014. Trend equation of classified loan of Rajshahi Krishi Unnayan Bank is positive and goodness of fit of equation is very high i.e. $70 \%$. From this study, it is found that amount of operating expense is more than amount of operating income in every year except in year 2009-2010. From the capital adequacy ratio analysis we have observed that it is expressed as a percentage of a bank's risk weighted credit exposures. This ratio is used to protect depositors and promote the stability and efficiency of financial systems around the world. Growth pattern fluctuate from one year to another year. But the fluctuation range was big, so it indicates that the financial system of Rajshahi Krishi Unnayan Bank, Bangladesh is not stable.

\section{Limitations, Recommendations and Conclusion}

\subsection{Limitations of the Study}

Although the present study has supplied useful information about Performance Evaluation of Rajshahi Krishi Unnayan Bank (RAKUB) in Bangladesh, but it is not free from limitations. This study has several limitations that must be acknowledged. The study has the following limitations-

i The main limitation of this report is that it is based on primary data and secondary data. Although the study suffers from the lack of corresponding primary data.

ii Some desired information could not be collected due to confidentially of bank.

iii Most of the time RAKUB's employees was very busy. So they can't provide enough time to get information for preparing this report.

iv The most functions of RAKUB are manual and lengthy though it is trying to upgrade..

$\mathrm{v}$ The study also relied on various publications, journals, annual reports and relevant web sites. But these analyses did not provide country specific updated information.

vi Library management and functioning is not satisfactory at many places and much of the time and energy of us are spent in tracing out of Books, Journals, and Reports etc.

viiI have faced some problems while conducting the research on data collection due to lack of practical experiences in the relevant field of research.

\subsection{Recommendations}

The following recommendations are provided to the bank:

- Rajshahi Krishi Unnayan Bank (RAKUB) should increase the employment opportunities for the betterment of welfare of the society.

- Rajshahi Krishi Unnayan Bank (RAKUB) should establish available branches all over the country in appropriate location.

- RAKUB have to emphasize on recovery department to reduce the classified loan.

- RAKUB need to increase net income by decreasing expense.

- RAKUB need to expand the branches to collect more deposit and increase net income. 
- Rajshahi Krishi Unnayan Bank (RAKUB) should increase Capital Market and Financial Instruments.

- Rajshahi Krishi Unnayan Bank (RAKUB) should manage Cost of Information, Control over Cost of Fund, Mark-up Financing, Utilization of Interest Rate for Fixing the Profit Margin. Social Concerns, enabling those who have no property, providing employment opportunities to all categories of people.

- RAKUB should Establish Co-operation among Themselves.

- Rajshahi Krishi Unnayan Bank (RAKUB) should finance to high-return projects \& profitable use of surplus funds.

- Need to increase concentration to capital market investment $\&$ inter-bank money market.

- Sources and nature of income and expenditure should be disclosed in the income statement to ensure that their income and expenditure were earned according to banks rules and regulations.

\subsection{Conclusion}

The journey of Rajshahi Krishi Unnayan Bank (RAKUB) started functioning on 15 March 1987. After commencement the banks play a vital role in the economic development of the country. It is reflected from the analysis that almost every year the bank has opened new branches. The growth of branches is positive for every year i.e. upward trends. But, in 2013-2014 has highest number of Branches i.e. 377.The highest growth percentage is in 20112012 \& lowest is in 2013-2014. Trend equation of branches of Rajshahi Krishi Unnayan Bank is positive and goodness of fit of equation is very high i.e. $90 \%$. However, the bank should open up more new branches for the overall development of agricultural sector of Bangladesh. Rajshahi Krishi Unnayan Bank (RAKUB) has created employment opportunities for more than four thousand people in Bangladesh. From the trend analysis we have observed that $\left(\mathrm{r}^{2}\right)$ of employees of the banks are more than $68 \%$. However the banks should take remedial measures to reduce their employee turnover. The growth of deposit is positive for every year but negative in year 2010-2011. In year 20132014 has highest deposit i.e. 3050.13 Crore. The highest growth percentage is in 2013-2014 \& lowest is in 20102011. Trend equation of deposit of Rajshahi Krishi Unnayan Bank is positive and goodness of fit of equation is high i.e. $59 \%$. It indicates the banks will be able to attract more deposit in the future years. It will encourage small savers to save more and allocate their saving in the overall improvement of the country. We have found that RAKUB has reduced their loan disbursement gradually throughout the years. From the trend analysis we have found that the trend values for loan of the bank is positive which indicates that the bank will increase the amount of loan disbursement in future. The loan interest rate also shows a declining pattern which will encourage small and medium entrepreneurs to take loans from this bank. It is observed that RAKUB does not sanction adequate loan in large and medium agro based industry. So, RAKUB should give attention for large and medium industry more and may allocate more loans in this sector. At the same time the bank should focus more on small and cottage industry. This is an important sector which helps many landless and unemployed people to become self dependant and thereby earn their livelihood. So, adequate loan disbursement with easy formalities by the bank in this sector is a must. However, from the trend analysis, by testing the trend values and $\left(\mathrm{r}^{2}\right)$ we are quite optimistic that in the future the bank will give proper attention in both the sector by allocating more loans for agro based industry. RAKUB should concentrate more on loan recovery. It is reflected from the analysis that there is no consistent pattern for agricultural loan disbursement and recovery. However, the scenario is relatively better for industrial loan disbursement and recovery. It is recommended that the bank should disburse loan for easy condition and should set a target for loan recovery in both the sectors. It is always better if the bank can recover loan at a consistent pattern in every year. Otherwise the bank's profitability can be hampered. Bank should formulate policy to appreciate its strengths and remove weakness to ensure its growth and expansion and greater contribution towards agricultural development of Bangladesh. We are quite optimistic that if the given suggestions of this paper are implemented then the Rajshahi Krishi Unnayan Bank may be able to overcome its present problems and may contribute in the rapid development of the agricultural sector of Bangladesh.

\section{References}

[1] Shah Johir Rayhan, S. M. Sohel Ahmed, and Ripon Kumar Mondal. (2011). Performance Evaluation and Competitive Analysis of State Owned Commercial Banks in Bangladesh. Research Journal of Finance and Accounting, Vol 2, No 3, 99114.

[2] Islam, Siddiqui, Hossain. (2014). Performance Evaluation of the Banking Sector in Bangladesh: A Comparative Analysis. Business and Economic Research, Vol. 4, No. 1, 70-106.

[3] Md Reaz Uddin, and Jannatul Ferdous Bristy. (2014). Evaluation of Some Private Commercial Banks in Bangladesh from Performance Perspectives. International Journal of Managing Value and Supply Chains (IJMVSC) Vol. 5, No. 4, $1-17$.

[4] Suat Teker1, Dilek Teker and Oya Kent. (2011). Measuring Commercial Banks' Performances in Turkey: A Proposed Model. Journal of Applied Finance \& Banking, vol.1, no.3, 2011, 97-112.

[5] Md. Zakir Hossain, Afjal Hossain, Dhanonjoy Kumar, Shaikh Masrick Hasan, and Md. Farijul Islam. (2012). Financial Performance Analysis of NCBs in Bangladesh. A case Study on Janata Bank Limited. Bangladesh Research Publications Journal, Vol. 7, Issue: 4, 428-436.

[6] Tanbir Ahmed Chowdhury and Salma Chowdhury. (2011). Performance Evaluation of Agricultural Banks in Bangladesh. International Journal of Business and Management, Vol. 6, No. 4, 75-89. 
[7] B. Nimalathasan. (2008). A comparative study of financial performance of banking sector in Bangladesh - An application of CAMELS rating / Annals of University of Bucharest, Economic and Administrative Series, 141-152.

[8] Richard S. Barr, Kory A. Killgo, Thomas F. Siems and Sheri Zimmel. (1999). Evaluating the Productive Efficiency and Performance of U.S. Commercial Banks. Managerial Finance, Vol. 28, Issue 8, 1-39.

[9] Bishnu Pada Banik and Prahallad Chandra Das. (2013). Comparison of Financial Performance of State Owned Commercial Banks: A Case Study of Bangladesh. International Journal of Science and Research (IJSR), Vol. 2, Issue 2, 423-428.

[10] Shah Md. Al Emran Sarker and Amitav Saha. (2011). Performance Indicators of Banking Sector in Bangladesh: A Comparative Study. ASA University Review, Vol. 5 No. 1, 21-36.
[11] Shawgat S. Kutubi. (2011). Board of Director's Size, Independence and Performance: An Analysis of Private Commercial Banks in Bangladeshi. World Journal of Social Sciences, Vol. 1. No. 4, 159-178.

[12] Hossain, Abdullah and Farhana. (2012). Performance Appraisal \& Promotion Practices on Private Commercial Bank in Bangladesh: A Case Study from Pubali Bank Ltd. Asian Business Review, Vol. 1, Issue 1, 49-55.

[13] A A Rushdi. (2009). Performance Measure for the Commercial Banks in Bangladesh: An Application of Total Factor Productivity. AIUB Bus Econ Working Paper Series, No 2009-01, 1-21.

[14] Review of Annual Report of Rajshahi Krishi Unnayan Bank of 2009-2010, 2010-2011, 2011-2012, 2012-2013, and 20132014. 